\title{
Utility of screening asymptomatic adults with thyroid ultrasonography
}

\section{Asemptomatik erişkinlerde taramasının yararlılığı}

ultrasonografi

\section{Abdulhalim Senyıgıt ${ }^{1}$, Esra Hatipoglu², Okan Gurkan ${ }^{3}$, İlhami Gultepe ${ }^{4}$, Timur Orhanoglu ${ }^{1}$, Yeltekin Demire $^{5}$}

${ }^{1}$ Biruni University Faculty of Medicine, Department of Internal Medicine, Istanbul, Turkey.

${ }^{2}$ Biruni University Faculty of Medicine, Division of Endocrinology and Metabolism, Department of Internal Medicine, Istanbul, Turkey.

${ }^{3}$ Biruni University Faculty of Medicine, Department of Radiology, Istanbul, Turkey.

${ }^{4}$ Altınbas University, Department of Internal Medicine, Medicine Faculty, Istanbul, Turkey.

${ }^{5}$ Sivas Cumhuriyet University Faculty of Medicine, Department of Family Medicine, Sivas, Turkey.

Corresponding author: Esra Hatipoğlu, MD, Biruni University Faculty of Medicine, Division of Endocrinology and Metabolism, Department of

Internal Medicine, Istanbul, Turkey

E-mail: dresrah@gmail.com

Received/Accepted: February 26, 2019 / March 26, 2019

Conflict of interest: There is not a conflict of interest.

\section{SUMMARY}

Objective: In this study we aimed to determine whether thyroid USG is useful in the absence of any complaints and prominent self/family history or risk of thyroid pathology.

Method: Thyroid USG results of 1198 asymptomatic adults, who had no self or family history of any thyroid pathology, were retrospectively included. In all cases USG was done by the same radiologist. Thyroid nodules were classified based on their sonographic characteristics suspicious for malignancy according to American Thyroid Association (ATA)-2015 guideline.

Results: Based on ATA-2015 criteria 5\% ( $\mathrm{n}=61)$ detected nodule with high risk and $27 \%(\mathrm{n}=325)$ detected nodule with intermediate risk for malignancy. Three percent $(n=33)$ had nodules with low risk for malignancy based on USG findings.

Conclusions: USG alone may not be a decisive screening tool for thyroid carcinoma. Personal/family history and risks may guide in which cases thyroid USG would be more reliable.

Keywords: Thyroid, ultrasonography, nodule, malignancy

\section{ÖZET}

Amaç: Bu çalışmada her hangi bir şikayet veya tiroid kanseri için belirgin bir risk faktörü olmaksızın çekilen tiroid USG'lerinin faydasını belirlemeyi hedefledik.

Yöntem: Tiroid kanseri için her hangi bir ailesel veya kişisel risk faktörü olmayan 1198 asemptomatik bireyin çekilmiş olan tiroid USG sonuçları retrospektif olarak incelendi. Tüm USG ler aynı radyolog tarafından yapılmıştı. Tiroid nodülleri American Thyroid Association (ATA)-2015 kılavuzuna göre sınıflandırılmıştı.

Bulgular: ATA-2015 kriterlerine göre saptanan nodüllerin \% $\%$ 'i ( $\mathrm{n}=61)$ yüksek risk grubunda iken $\% 27$ 'si $(\mathrm{n}=325)$ orta risk grubunda idi. Yüzde 3 (n=33)'ü ise malignite açısından düşük riskli grupta idi.

Sonuç: Tiroid kanserini saptamada USG tek başına güvenilir bir metod olmayabilir. Kişisel/ailevi anamnez ve risk faktörleri tiroid USG'sinin daha güvenilir olabileceği vakaları seçmede yardımcı olabilirler.

Anahtar sözcükler: Tiroid, ultrasonografi, nodül, malignite

\section{INTRODUCTION}

The wide spread use of ultrasonography (USG) in recent years has increased the detection rate of thyroid nodules. While the incidence is $3-7 \%$ on palpation, the incidence of thyroid nodules detected by USG is \%20-76 ${ }^{1}$. In accordance with these data, sonographic prevalence of the thyroid nodules is $24 \%$ between ages 18 and 65 , while it increases up to $37 \%$ above age 65 in our region ${ }^{1}$. USG is of utmost importance in diagnosing thyroid nodules, detecting their size, characteristics and presence of lymph nodes ${ }^{2}$. Its 
noninvasiveness and absence of ionizing radiation renders it a safe option.

Several health ckeck-up programmes include thyroid USG. However thyroid USG is operator dependent and whether this changes the management of nodules is still controversial ${ }^{3,4}$. In this paper we aimed to determine whether thyroid USG is necessary in the absence of any complaints and prominent self/family history or risk of thyroid pathology.

\section{MATERIAL AND METHODS}

In this study 1198 thyroid USG results, which were obtained between 2013 and 2015, were retrospectively examined. Results obtained from asymptomatic adults, who had no self or family history of any thyroid pathology were included. Cases with any risk factors for thyroid malignancy were excluded. The study protocol was approved by the Local Ethics Commitee of Biruni University. All the tenets of the declaration of Helsinki were adhered to.

In all cases USG was performed using $12 \mathrm{MHz}$ linear probe (Logiq 9; GE, Wauwatosa, WI, USA) by the same radiologist, at the same room temperature, while the patient at supine position with the head leaning back to expose the anterior part of the neck. If the nodüle was present, it was described according to its location, size, borders, echogenicity, and calcifications. In case of multiple nodules findings of suspicious or dominant nodule was recorded. Based on USG findings three signs were chosen to assess the possibility of malignancy: (1) irregular boundary, (2) hypoechogenicity in comparison to the echogenicity of the muscles of anterior part of the neck; (3) internal microcalcifications (diameter of hyperechoic spots $<1 \mathrm{~mm}$ ) of the nodules ${ }^{5}$. Pathologic results were obtained retrospectively for the nodules which were biopsied.

The data were statistically analyzed with the SPSS 17.0 package program. Chi-square test was used for categorical variables. Continuous variables with normal distribution were compared between 2 groups by using student-t test and between multiple groups by using one-way ANOVA test. Post-hoc analysis was also performed for the results with significant difference. $\mathrm{p}<0.05$ was considered statistically significant.

\section{RESULTS}

The mean age of the included cases was $49.5 \pm 15$ years. Of the all cases $606(51 \%)$ were female and $592(49 \%)$ were male. Thirtyfive percent $(n=421)$ of the USG results included one or more nodules. Of these $16 \%(n=68)$ were solitary and $84 \%$ $(n=353)$ were multiple nodules. The mean diameter of the nodules was $13.5 \pm 8.6 \mathrm{~mm}$. Adults with nodules were older than those without nodules $(51.2 \pm 14.3$ years and $48.5 \pm 15.4$ years, respectvely. $\mathrm{p}=0.003$ ). Female/male ratio was 1.6 in cases with nodules while it was 0.8 in those without nodules $(\mathrm{p}<0.001)$.

Based on ecogenity nodules were divided in 4 categories; hypoecogenic [91\%( $\mathrm{n}=384)]$, hyperecogenic $\quad[3 \%(\mathrm{n}=12)], \quad$ isoecogenic $[5 \%(n=23)]$ and heterogenous $[1 \%(n=2)]$. Seven percent $(n=30)$ of the nodules had irregular borders while $93 \%(n=389)$ had regular borders. Microcalcification was detected in $10 \%(\mathrm{n}=42)$ of the nodules.

Among all USG findings, 2\% $(\mathrm{n}=28)$ of cases included hypoecogenic nodules with irregular borders and, 3\% ( $\mathrm{n}=40)$ had hypoecogenic nodules with microcalcification (7 of the hypoecogenic nodules had both irregular borders and microcalcification). Based on American Thyroid Association (ATA)-2015 criteria $^{5}$, of the all 1198 USG findings obtained from asymptomatic adults with low risk of thyroid malignancy, $5 \%(\mathrm{n}=61)$ detected cases with high risk nodules and $27 \%(n=325)$ detected cases with intermediate risk nodules (Fig. 1). Three percent $(n=33)$ of cases had nodules with low risk for malignancy based on USG findings. Among intermediate and high risk groups of the nodules which were biopsied, 2 had papillary thyroid carcinoma. 


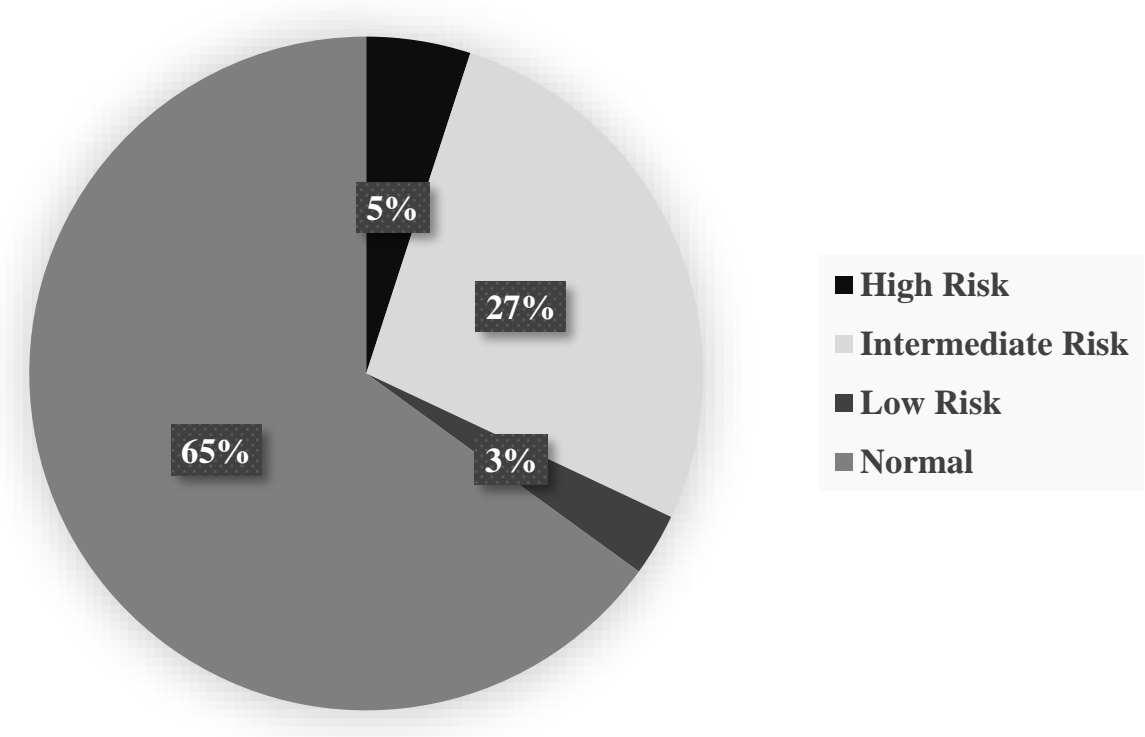

Figure 1. Risk rates for malignancy

When the USG findings within nodules were stratified by ATA-2015 criteria, adults with high risk nodules were $52.5 \pm 13.9$ years old, adults with intermediate risk nodules were $50.9 \pm 14.3$ years old and adults with low risk nodules were $51.1 \pm 15.4$ years old $(p=0.7)$. Female/male ratio in high risk, intermediate risk and low risk groups were $49 / 13(79 / 21 \%), 189 / 135(58 / 42 \%)$ and 21/12 (64/36\%) $\quad(\mathrm{p}=0.009)$. Additional characteristics of the nodules are presented in Table 1. Post-hoc comparisons indicated that the mean diameter of intermediate risk nodules was lower than the mean diameter of high risk and low risk nodules $(\mathrm{p}<0.001)$. The mean diameter was not different between high and low risk groups $(\mathrm{p}=0.5)$. The nodules in high and intermediate risk groups were more hypoecogenic in comparison to low risk group $(\mathrm{p}<0.001)$. In the high risk group microcalcification and irregular border were more frequent than those in intermediate and low risk groups $(\mathrm{p}<0.001)$.

Table 1. Comparison of USG findings between nodules based on stratification by risk for malignancy

$\begin{array}{llc}\begin{array}{l}\text { High risk } \\ (\mathrm{n}=62)\end{array} & \text { Intermediate risk } & \text { Low risk } \\ (\mathrm{n}=325) & (\mathrm{n}=33)\end{array}$

Nodule diameter $(\mathrm{mm})^{\mathrm{a}}$

$19.2 \pm 11.03$

$12.1 \pm 7.2$

$17.3 \pm 10.4$

$<0.001 *$

Hypoecogenity $(\mathrm{n}, \%)^{\mathrm{b}}$

$61(98 \%)$

$321(99 \%)$

$0(0 \%)$

$<0.001 *$

Microcalcification (n,\%) ${ }^{\mathrm{b}}$

$41(66 \%)$

$1(0.3 \%)$

$0(0 \%)$

$<0.001$ *

Irregular border $(\mathrm{n}, \%)^{\mathrm{b}}$

$28(45 \%)$

$2(1 \%)$

$0(0 \%)$

$<0.001 *$

Solitary nodule $(\mathrm{n}, \%)^{\mathrm{b}}$

$7(11 \%)$

$51(16 \%)$

$9(27 \%)$

0.13

${ }^{\mathrm{a}}$ One-way Anova test was used to compare groups. ${ }^{\mathrm{b}}$ Groups were compared using chi-square test

* denotes statistically significant results 


\section{DISCUSSION}

Thyroid nodule is a common clinical entity. The lifetime risk for developing a thyroid nodule is 5$10 \%$, with USG it has increased up to $19-68 \%{ }^{5}$. The incidence of thyroid nodules detected by USG is $20-76 \%{ }^{1}$. In line with this data in the current study the incidence of thyroid nodules detected by USG was $35 \%$ and nodules were more common in females. Also nodules were more prevalent in older population.

In 2015 ATA published a new guideline for management of thyroid nodules and classified them based on their sonographic patterns ${ }^{5}$. Presence of hypoecogenity together with microcalcification, irregular border or tall shape depicted as high risk group; presence of hypoecogenity alone depicted as intermediate risk group and, many other findings depicted low, very low risk and benign nodules. Microcalcification and irregular borders are among the USG features which have the highest specifities for thyroid carcinoma albeit low sensitivity ${ }^{5}$ Each sonographic class of nodules has different risk of malignancy , $>70-90 \%$ for highy risk, $10-20 \%$ for intermediate risk and 5-10\% for low risk nodules ${ }^{5}$.

In the current cohort of asymptomatic adults, who had no known risk for thyroid carcinoma, 5\% of the USG revealed high risk nodules, $27 \%$ revealed intermediate risk and 3\% revealed low risk nodules. Only 2 of the nodules were proven to be malign after fine needle aspiraiton. This may indicate that being highly suspicous for malignancy based on ultrasonography may not mean to be really malign. Additionally, female cases, hypoecogenity, microcalcification and irregular borders were more frequent in the high risk group. Interestingly age was not different among risk groups and diameter of nodules was higher in intermediate group but not in high risk group.

It may be assumed that USG has a pivotal role in early diagnosis of thyroid carcinoma, however our findings showed that of the 1198 USG results only $5 \%$ detected highly suspicious nodules. When, relatively low $(55 \%)$ specifity of one or more malign features in thyroid USG is taken into consideration, USG may not be that decisive ${ }^{6,7}$. Moreover rate of increase in incidence of thyroid carcinoma has decreased to 2.1 per year from 2009 to 2013 and, mortality is 0.7 death/100000 person/year ${ }^{8}$. Thyroid carcinoma generally has good prognosis 9. Besides, it is controversial whether early treatment changes the outcome ${ }^{10-12}$. Therefore there is not enough evidence to support the recommendation for thyroid carcinoma screening with USG or palpation in asymptomatic individuals 5,13 .

Current study was not without limitations. Data on height to width ratio of nodules and lymph nodes were lacking. Retrospective nature of the study caused these restrictions, with a prospective study these limitations may be overcome.

In conclusion USG can detetct highly suspicious nodules only 5\% of asymptomatic adults. This may indicate that thyroid USG alone is not a decisive screening tool for thyroid carcinoma. Personal/family history and risks may guide in which cases thyroid USG would be more reliable.

\section{REFERENCES}

1. Turkiye Endokrinoloji ve Metabolizma Dernegi-Tiroid hastalıkları tanı ve tedavi kılavuzu 2016

Ankara , Turkiye: Turkiye Klinikleri Yayın 2017.

2. Yeh MW, Bauer AJ, Bernet VA, et al. American Thyroid Association statement on preoperative imaging for thyroid cancer surgery. Thyroid : official journal of the American Thyroid Association. 2015; 25: 3-14.

3. Mazzaglia PJ. Surgeon-performed ultrasound in patients referred for thyroid disease improves patient care by minimizing performance of unnecessary procedures and optimizing surgical treatment. World journal of surgery. 2010; 34: 1164-70.

4. Nilakantan A, Venkatesh MD, Raghavan D, Datta R and Sharma V. Ultrasonography: Its role in nodular thyroid disease. Indian journal of otolaryngology and head and neck surgery : official publication of the Association of Otolaryngologists of India. 2007; 59: 332-5.

5. Haugen BR, Alexander EK, Bible KC, et al. 2015 American Thyroid Association Management Guidelines for Adult Patients with Thyroid Nodules and Differentiated Thyroid Cancer: The American Thyroid Association Guidelines Task Force on Thyroid Nodules and Differentiated Thyroid Cancer. Thyroid : official journal of the American Thyroid Association. 2016; 26: 1-133.

6. Kim SJ, Moon WK and Cho N. Sonographic criteria for fine-needle aspiration cytology in a Korean female population undergoing thyroid ultrasound screening. Acta radiologica (Stockholm, Sweden : 1987). 2010; 51: 475-81.

7. Kim JY, Lee CH, Kim SY, et al. Radiologic and pathologic findings of nonpalpable thyroid carcinomas detected by ultrasonography in a 
medical screening center. Journal of ultrasound in medicine : official journal of the American Institute of Ultrasound in Medicine. 2008; 27: 215-23.

8. In: Howlader N NA, Krapcho M, Miller D, Bishop K, Altekruse SF, Kosary CL, Yu M, Ruhl J, Tatalovich Z, Mariotto A, Lewis DR, Chen HS, Feuer EJ, Cronin KA, (ed.). SEER Cancer Statistics Review, 1975-2013, National Cancer Institute,Bethesda, MD

April 2016.

9. Cooper DS, Doherty GM, Haugen BR, et al. Revised American Thyroid Association management guidelines for patients with thyroid nodules and differentiated thyroid cancer. Thyroid : official journal of the American Thyroid Association. 2009; 19: 1167-214.

10.Ito $\mathrm{Y}$, Miyauchi $\mathrm{A}$, Inoue $\mathrm{H}$, et al. An observational trial for papillary thyroid microcarcinoma in Japanese patients. World $J$ Surg. 2010; 34: 28-35.

11.Ito Y, Miyauchi A, Kihara M, Higashiyama T, Kobayashi $\mathrm{K}$ and Miya A. Patient age is significantly related to the progression of papillary microcarcinoma of the thyroid under observation. Thyroid : official journal of the American Thyroid Association. 2014; 24: 27-34.

12. Oda $\mathrm{H}$, Miyauchi $\mathrm{A}$, Ito $\mathrm{Y}$, et al. Incidences of Unfavorable Events in the Management of LowRisk Papillary Microcarcinoma of the Thyroid by Active Surveillance Versus Immediate Surgery. Thyroid : official journal of the American Thyroid Association. 2016; 26: 150-5.

13.Bibbins-Domingo K, Grossman DC, Curry SJ, et al. Screening for Thyroid Cancer: US Preventive Services Task Force Recommendation Statement. Jama. 2017; 317: 1882-7. 